\title{
Substitution of wheat bran by corn gluten feed without steep water in cats feed
}

\author{
Lívia Geraldi Ferreira ${ }^{1}$ Juliana de Melo Pires $^{2}$ Márcio Gilberto Zangeronimo ${ }^{1^{*}}$ \\ Flávia Maria de Oliveira Borges Saad ${ }^{3}$ Roberta Ariboni Brandi ${ }^{2}$ Ives Cláudio da Silva Bueno ${ }^{2}$ \\ Priscila Barros Barbosa ${ }^{3}$ Karen Guttenkunst Lisenko ${ }^{3}$ Taís Regina Taffarel ${ }^{3}$ Jéssica Santana dos Reis $^{3}$
}

${ }^{1}$ Departamento de Medicina Veterinária, Universidade Federal de Lavras (UFLA), 37200-000, Lavras, MG, Brasil. E-mail: zangeronimo@dmv.ufla.br. ${ }^{*}$ Corresponding author.

${ }^{2}$ Departamento de Zootecnia, Universidade de São Paulo (USP), Pirassununga, SP, Brasil.

${ }^{3}$ Departamento de Zootecnia, Universidade Federal de Lavras (UFLA), Lavras, MG, Brasil.

ABSTRACT: This study aimed to evaluate the effects of substituting wheat bran (WB) by corn gluten feed without steep water (CGF) in cats feeds regarding the nutritional value of the diet, stool characteristics, time of food passage through the gastrointestinal tract (GIT), intestinal gas production and concentrations of short chain fatty acids (SCFA) in blood and faeces. Twenty eight cats were distributed in a randomized block design with four treatments (0, 2.6, 5.3 or 8.0\% CGF, based on dry matter, substituting for WB) and seven replicates. Substitution of $W B$ by $C G F$ decreased $(P<0.01)$ the digestibility of acid detergent fibre without influencing $(P>0.05)$ the digestibility of other nutrients and apparent metabolizable energy. There was also no effect $(P>0.05)$ on faeces moisture, faecal pH and score, food transit time in the GIT, intestinal gas area and SCFA concentrations in faeces, while blood concentrations of propionate were influenced differently by the different feeds and sampling times $(P<0.05)$. Thus replacement of up to $8 \%$ of WB by CGF may be done safely in cats feed.

Key words: agro-industrial by-product, dietary fibre, digestibility, felines, fermentation.

Substituição do farelo de trigo pelo farelo de casca de milho sem água de maceração em alimentos para gatos

RESUMO: Objetivou-se avaliar os efeitos da substituição do farelo de trigo (FT) pelo farelo de casca de milho sem água de maceração (FCM) em alimentos completos para gatos sobre a digestibilidade dos nutrientes, características das fezes, tempo de passagem do alimento pelo trato gastrintestinal (TGI), produção de gás intestinal e concentrações de ácidos graxos de cadeia curta (AGCC) no sangue e nas fezes. Foram utilizados 28 gatos, os quais foram distribuídos em um delineamento em blocos casualizados com quatro tratamentos (0, 2,6, 5,3 e 8,0\% de FCM, com base na matéria seca, em substituição ao FT) e sete repetições. A substituição do FT pelo FCM reduziu (P<0,01) a digestibilidade da fibra em detergente ácido, sem influenciar $(P>0,05)$ a digestibilidade dos demais nutrientes e a energia metabolizável das dietas. Também não houve efeito $(P>0,05)$ sobre a umidade das fezes, o escore e o $\mathrm{pH}$ fecal, o tempo de passagem do alimento no TGI, área de gás intestinal e concentrações AGCC nas fezes, enquanto as concentrações sanguíneas de propionato foram influenciadas de maneira diferente entre as diferentes dietas e tempos de coleta. Conclui-se que a substituição do FT pelo FCM, até 8\%, pode ser feita de maneira segura em alimentos para gatos.

Palavras-chave: co-produto agroindustrial, digestibilidade, felinos, fermentação, fibra.

\section{INTRODUCTION}

Currently, there is great pressure both politically and socially to decrease the amount of agro-industrial waste discarded in the environment. Thus, numerous alternatives for disposal of these wastes have been proposed, among them their use as a source of nutrients in animal feed. Corn is produced in large quantities throughout the world and its processing for the manufacture of products for human consumption leads to several agro-industrial by-products, including corn gluten feed without steep water (CGF), which is composed mainly by corn husk. According to SUGAWARA et al. (1994), corn husk is composed mainly of cellulose $(16 \%)$ and hemicelluloses $(72 \%)$ and can be used as a source of fibre in animal feed.

Wheat bran (WB) is another by-product produced in large quantities after milling of white flour for human consumption. This grain is composed mainly of arabinoxylans (36.5\%), cellulose $(11 \%)$, lignin (3 to $10 \%$ ) and uronic acid (3 to $6 \%$ ). Although the digestibility of its constituents by the digestive enzymes of monogastric animals is low, WB is commonly employed in animal feed as a source of fibre (BERGMANS et al., 1996).

Fibre does not comprise a significant portion of the natural diet of cats; however, the microbiome of the feline GI tract has the ability to metabolize fibrous substrates (SUNVOLD et al., 
1995). Indeed, the inclusion of this nutrient in the diet has a significant role in the prevention and mitigation of various physiological and metabolic disorders that are increasingly more common in cats, including obesity and colitis. These features emphasize the importance of studying the effects of fibre in the diet of cats.

Therefore, although corn husk presents a great potential to be used as a fibre source in animal feed, researches involving this ingredient in the nutrition of cats are still scarce. Thus, this study aimed to evaluate the effect of substituting WB with CGF in feed for cats on nutrient digestibility, stool characteristics, time of passage of food through the gastrointestinal tract (GIT), production of intestinal gas and concentrations of short-chain fatty acids (SCFA) in blood and faeces.

\section{MATERIALS AND METHODS}

Twenty-eight adult cats, weighing $3.53 \pm 0.82 \mathrm{~kg}$, mixed breed, male and female were kept in metabolic cages $60 \times 50 \times 70 \mathrm{~cm}$ (height $\mathrm{x}$ width $\mathrm{x}$ depth) throughout the experimental period. The animals were weighed at the beginning of the experiment and distributed in a randomized block design consisting of four treatments and seven replicates, with the blocks determined by animals weight. The experimental period lasted 15 days, including five days for adaptation to the experimental diets and 10 days for data collection.

The complete feeds were formulated to meet the animal category, with increasing amounts of CGF replacing WB (Table 1). The four treatments were: feed $1(17.5 \% \mathrm{WB})$; feed $2(15.0 \% \mathrm{WB}$ and $2.6 \%$ $\mathrm{CGF})$; feed $3(12.3 \% \mathrm{WB}$ and $5.3 \% \mathrm{CGF})$ and feed 4 (9.8\% WB and $8.0 \% \mathrm{CGF}$ ). Before the beginning of the experiment, a pilot test was conducted to verify the acceptability of the experimental diets by the animals and it was decided to add water and moist pet food to the diets (in the ratio of 1:1:1 of experimental diet: water: moist pet food) to enhance the interest of animals in the feeds. The amount of feed supplied to each animal was determined according to the recommendations of the National Research Council (NRC, 2006) for maintenance of adult cats. This quantity was divided into two meals at $8 \mathrm{am}$ and at $5 \mathrm{pm}$.

Faeces were collected every morning and evening before the daily feedings. The material collected was weighed, placed in plastic bags and stored in a freezer at $-20^{\circ} \mathrm{C}$. Prior to collection, the faecal score was assessed according to the scale proposed by deOLIVEIRA et al. (2008), in which 1 corresponds to watery faeces and 5 to hard, dry and well-formed faeces. At the end of the experiment, faeces were thawed and faecal samples from each animal were homogenized and stored in a forced air oven at $65^{\circ} \mathrm{C}$ for 72 hours. Samples were weighed and grounded in a ThomasWiley hammer mill, using a $1 \mathrm{~mm}$ screen.

Analyses of dry matter (DM) (method 934.01), crude protein (CP) (method 954.01), acidhydrolyzed fat (AHF) (method 954.02) and ashes (AS) (method 942.05) of feeds and faeces were performed according to methods described by the Association of Official Analytical Chemists (AOAC, 1995). Organic matter was calculated by difference $(\mathrm{OM}=100-\mathrm{ash})$. Neutral detergent fibre (NDF) and lignin were analyzed according to ROBERTSON \&VAN SOEST (1981). Acid detergent fibre (ADF) was analyzed according to VAN SOEST (1963). Food and faeces gross energy contents were determined using a bomb calorimeter (C200System, IKA, Campinas, SP, Brazil). For the apparent metabolizable energy (AME), a formula for urinary correction, established by ANFALPet (2009) was used.

Radiographic analyses were performed using a ray generator XAltus ST503HF (Sawae ${ }^{\circledR}$, Nova Lima, MG) and Kodak $^{\circledR}$ films $(24 \times 30 \mathrm{~cm})$. Each animal was imaged in two positions: left lateral-lateral and ventrodorsally. Then, images were photographed, digitized and evaluated using the software Image $\mathbf{J}^{\circledR}$ as described by FELICIANO et al. (2010).

The time of passage of food through the GIT was determined by the addition of $0.1 \%$ chromic oxide to the food. The time between the first intake of food and excretion of greenish faeces was recorded, corresponding to transit time in the GIT. In the same period, faecal $\mathrm{pH}$ was also determined using a digital pHmeter (model Q400A, QUIMIS, Diadema, SP, Brazil) with the electrode inserted directly into the sample.

Fresh faecal samples (collected no more than 15 minutes after defecation) were immediately placed in plastic bags and stored in a freezer at $-20^{\circ} \mathrm{C}$. Later, $5 \mathrm{~g}$ of faeces were added to $15 \mathrm{ml}$ of distilled water. This mixture was homogenized, filtered and centrifuged for 25 minutes at $15000 \mathrm{rpm}$ in a refrigerated centrifuge at $5^{\circ} \mathrm{C}$. Then, the supernatants of the samples were pipetted, properly identified and stored in a freezer at $-15^{\circ} \mathrm{C}$. Acetic, propionic, isobutyric, butyric, valeric and isovaleric acids were analysed by gas chromatography.

On the last day of the experiment blood samples were collected in heparinized tubes, from jugular vein, pre-feeding and four and eight hours post-feeding. Samples were centrifuged at 15000rpm for 10 minutes and then, the plasma was placed in polypropylene tubes and stored at $-20^{\circ} \mathrm{C}$. For the analysis of SCFA concentrations, $1 \mathrm{~mL}$ of plasma was added to $5 \mathrm{~mL}$ of ethyl alcohol and then centrifuged at $3000 \mathrm{rpm}$ for 10 minutes. The supernatant was added to 
Table 1 - Ingredient and chemical composition of experimental diets ${ }^{1}$.

\begin{tabular}{|c|c|c|c|c|}
\hline \multirow{2}{*}{ Item } & \multicolumn{4}{|c|}{ 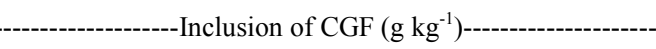 } \\
\hline & 0 & 26 & 53 & 80 \\
\hline Wheatbran & 200.00 & 170.00 & 140.00 & 110.00 \\
\hline Corn gluten feed without steep water & 0.00 & 30.00 & 60.00 & 90.00 \\
\hline Corngrain & 290.00 & 280.00 & 280.00 & 290.00 \\
\hline Rice grits & 210.00 & 210.00 & 210.00 & 210.00 \\
\hline Soybeanmeal 45/80 & 110.00 & 110.00 & 110.00 & 100.00 \\
\hline Meatandbonemeal & 60.00 & 60.00 & 60.00 & 50.00 \\
\hline Viscerameal & 80.00 & 90.00 & 90.00 & 100.00 \\
\hline Vitamin/mineral premix ${ }^{2}$ & 7.60 & 7.60 & 7.60 & 7.60 \\
\hline Poultryfat & 20.00 & 20.00 & 20.00 & 20.00 \\
\hline Palatant & 10.00 & 10.00 & 10.00 & 10.00 \\
\hline Zeolite & 10.00 & 10.00 & 10.00 & 10.00 \\
\hline Mouldinhibitor & 2.00 & 2.00 & 2.00 & 2.00 \\
\hline Taurina & 2.00 & 2.00 & 2.00 & 2.00 \\
\hline Yucca schidigeraextract & 0.25 & 0.25 & 0.25 & 0.25 \\
\hline Antioxidant & 0.15 & 0.15 & 0.15 & 0.15 \\
\hline \multicolumn{5}{|c|}{ 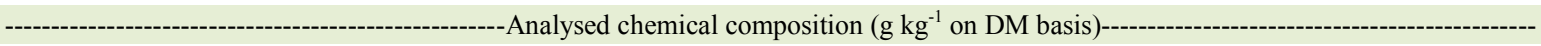 } \\
\hline Organic matter & 913.80 & 918.50 & 910.60 & 917.00 \\
\hline Crudeprotein & 297.20 & 312.60 & 295.90 & 282.80 \\
\hline Acid-hydrolyzed fat & 135.20 & 134.20 & 124.20 & 119.80 \\
\hline Neutral detergent fiber (aNDF) & 98.40 & 123.20 & 127.10 & 130.20 \\
\hline Acid detergent fiber (ADF) & 40.10 & 49.00 & 51.20 & 55.00 \\
\hline Lignin $(\mathrm{pm})$ & 13.60 & 16.20 & 17.00 & 18.10 \\
\hline Gross energy $\left(\mathrm{MJ} \mathrm{kg}^{-1}\right)$ & 19.50 & 19.70 & 19.40 & 19.50 \\
\hline
\end{tabular}

${ }^{1}$ The experimental diets were composed of a mixture of dry food, moist food, and water in a proportion of 1:1:1. Ingredient composition of moist food was: meat, meat by-products, chicken, chicken by-products, pork by-products, organic zinc, mannanoligosacharides, fish oil, chicken oil, powdered porcine plasma, taurine, potassium chloride, calcium carbonate, sodium tripolyphosphate, flavor, thickeners, dye, mineral vitamin premix, water.

${ }^{2}$ Per kg of diet: vitamin A, 10000IU; vitamin D3, 1500IU; vitamin E, 50IU; vitamin K, 0.55mg;vitamin B12, 30mcg; vitamin B1, 5.5mg; vitamin B2, 4mg; vitamin B6, 5.5mg; niacin, 50mg; biotin, $0.012 \mathrm{mg}$; pantothenic acid, 12mg; folic acid, 0.8mg; choline, 1200mg; cobalt, $0.2 \mathrm{mg}$; manganese, $40 \mathrm{mg}$; zinc, $120 \mathrm{mg}$; copper, $18 \mathrm{mg}$; iodine, $1.8 \mathrm{mg}$; iron, $80 \mathrm{mg}$; selenium, $0.12 \mathrm{mg}$.

$40 \mu \mathrm{L}$ of $1 \mathrm{mM} \mathrm{NaOH}$ and placed in a forced ventilation oven at $60^{\circ} \mathrm{C}$ until completely dry. Afterward, the residues were dissolved with $99 \%$ formic acid and $1 \mathrm{~mL}$ of distilled water and stored in a freezer at $-15^{\circ} \mathrm{C}$ until analysis of SCFA by gas chromatography.

The data were previously analyzed for normality (Shapiro-Willk test) and, when this assumption was accepted, data were submitted to analysis of variance and the means subjected to regression analysis when $\mathrm{P}<0.05$. The transit time, faecal score and SCFA concentrations in blood and faeces were analysed by Kruskal Wallis test. All statistical analyses were carried out in Action 2.4.

\section{RESULTS AND DISCUSSION}

The present study is the first to evaluate the effects of including CGF in diets for cats on nutrient digestibility, faecal characteristics, transit time of food through the GIT, intestinal gas area and concentrations of SCFA in blood and faeces. The CGF is an agroindustrial by-product that has the potential to be used as a source of fibre in cat diets. WB is also an agroindustrial by-product, but is commonly employed in animal feeding. Thus, the substitution of WB with CGF had as a main objective to compare the effects of the two fibrous substrates: wheat bran vs. a new source of fibre, CGF. This comparison allows verification of whether CGF inclusion in cat diets can be done safely.

The inclusion of CGF in place of WB did not affect $(\mathrm{P}>0.05)$ the CTTAD of DM, OM, CP, AHF and NDF or the AME of the diets (Table 2). According to MAES et al. (2004), WB, as well as corn husk, is mainly a source of insoluble fibre. Insoluble fibres have some important physiological effects, one being a reduction in the transit time of food through the GIT with consequent 
reduction in nutrient digestibility (DAVIDSON \&MCDONALD, 1998). In fact, some studies showed that supplementation of cat diets with WB promotes reduced digestibility of most nutrients when compared to diets without fibre supplementation (KIENZLE et al., 1991; FISCHER et al., 2012). KAWAUCHI et al. (2011) observed that, in dogs, the replacement of starch by maize gluten feed in proportions of 7, 14 or $21 \%$ led to a linear reduction in the digestibility of $\mathrm{DM}, \mathrm{CP}, \mathrm{AHF}$ and gross energy compared to a diet without inclusion of the ingredient. Thus, the absence of effects related to the digestibility of the nutrients found in the present study suggests a similarity between the quality of the fibre present in WB and CGF.

However, there was a linear decrease $(\mathrm{P}<0.01)$ in the digestibility of ADF as the level of CGF included was increased, what may be explained by the higher content of this nutrient in CGF $(21.3 \%$ dry matter) compared to WB (15.4\% dry matter). Moreover, as the level of CGF included was increased, the ADF content of the diet as well as the lignin content also increased. With regard to faecal characteristics, the inclusion of CGF did not influence $(\mathrm{P}>0.05)$ faecal output, moisture and score (Table 2). KIENZLE et al. (1991) reported that the addition of WB to a meat-based diet increased both the quantity of faeces excreted and the frequency of defecation in cats, while also increasing faecal moisture. Similar results were observed by FORTES et al. (2010) in dogs. However, in this case, the authors observed a higher percentage of DM in the faeces. As to corn fibre, as in the present study, GUEVARA et al. (2008) reported no differences in the weight of faeces from dogs that received a diet supplemented with this ingredient compared to animals fed with control diet. However, the moisture content of faeces from animals fed with corn fibre was less than that in the other animals' faeces, unlike what was observed in the present study, in which the median moisture content $(66.3 \%)$ was slightly higher in the faeces, resulting in a faecal score below the desired value (score 3 according to de-OLIVEIRA et al., 2008). This result can be explained by the higher content of insoluble fibre in the diet, which in turn promoted increased water retention in the faeces.

Moreover, the time of passage of food through the GIT of the animals was not influenced by the inclusion of CGF (Table 2). However, the large variability observed among animals, which can be associated with individual physiological functions of the GIT, must be considered. FAHEY et al. (1990) reported no differences in retention time in dogs fed with diets with different sources of fibre. The average retention time obtained by the authors was 28.3 hours, while in cats in the present study the mean retention time was 31.7 hours.

There were also no differences $(\mathrm{P}>0.05)$ in faecal $\mathrm{pH}$, intestinal gas area (Table 2), concentrations of total SCFA, acetate, propionate, isobutyrate, butyrate,

Table 2 - Coefficients of total tract apparent digestibility (CTTAD), apparent metabolizable energy (AME) of food, faecal characteristics, intestinal transit time and gas area of cats fed with diets with different amounts of corn gluten feed without steep water (CGF) substituted for wheat bran.

\begin{tabular}{|c|c|c|c|c|c|}
\hline \multirow{2}{*}{ Item } & \multicolumn{4}{|c|}{ 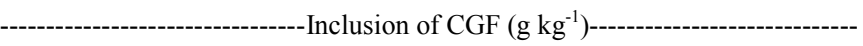 } & \multirow{2}{*}{ P-value } \\
\hline & 0 & 26 & 53 & 80 & \\
\hline \multicolumn{6}{|l|}{ CTTAD $\left(\mathrm{g} \mathrm{kg}^{-1}\right)$} \\
\hline Dry matter & $0.76 \pm 0.03$ & $0.76 \pm 0.05$ & $0.76 \pm 0.07$ & $0.73 \pm 0.05$ & 0.78 \\
\hline Organic matter & $0.79 \pm 0.03$ & $0.79 \pm 0.04$ & $0.79 \pm 0.06$ & $0.77 \pm 0.04$ & 0.67 \\
\hline Crude protein & $0.80 \pm 0.04$ & $0.81 \pm 0.04$ & $0.79 \pm 0.07$ & $0.77 \pm 0.04$ & 0.55 \\
\hline Acid-hydrolyzed fat & $0.81 \pm 0.05$ & $0.85 \pm 0.06$ & $0.81 \pm 0.08$ & $0.80 \pm 0.05$ & 0.34 \\
\hline Neutral detergent fiber (NDF) & $0.32 \pm 0.07$ & $0.43 \pm 0.09$ & $0.32 \pm 0.16$ & $0.35 \pm 0.11$ & 0.08 \\
\hline Acid detergent fiber (ADF) & $0.24 \pm 0.08$ & $0.16 \pm 0.05$ & $0.12 \pm 0.09$ & $0.10 \pm 0.15$ & $<0.001$ \\
\hline $\mathrm{AME}\left(\mathrm{MJ} \mathrm{kg}^{-1}\right)$ & $14.80 \pm 0.57$ & $14.80 \pm 0.85$ & $14.50 \pm 1.20$ & $14.30 \pm 0.80$ & 0.68 \\
\hline Faecal output (g DM basis/day) & $9.18 \pm 3.76$ & $10.55 \pm 4.24$ & $9.56 \pm 3.36$ & $11.40 \pm 4.54$ & 0.74 \\
\hline Faecal moisture (\%) & $65.01 \pm 5.98$ & $67.91 \pm 3.39$ & $66.73 \pm 6.30$ & $65.39 \pm 6.44$ & 0.54 \\
\hline Faecal score $^{1}$ & $3.33 \pm 0.56$ & $2.70 \pm 0.69$ & $3.17 \pm 0.62$ & $3.27 \pm 0.77$ & 0.49 \\
\hline Time of passage (hours) & $30.33 \pm 17.79$ & $27.79 \pm 14.70$ & $35.73 \pm 28.12$ & $32.89 \pm 30.17$ & 0.98 \\
\hline Faecal pH & $6.49 \pm 0.68$ & $6.01 \pm 0.74$ & $5.87 \pm 0.37$ & $6.03 \pm 0.58$ & 0.27 \\
\hline Gas area $\left(\mathrm{cm}^{2}\right)$ & $4.64 \pm 2.00$ & $4.42 \pm 1.50$ & $4.89 \pm 1.69$ & $4.97 \pm 1.15$ & 0.89 \\
\hline
\end{tabular}

${ }^{1} 1$ - watery, liquid that can be poured; 2 - soft, unformed, stool assumes shape of container; 3 - soft, formed, moist, softer stool that retains shape; 4 - hard, formed, dry stool, remains firm and soft; 5 - hard, dry pellets, small, hard mass. 
valerate and isovalerate in faeces (Table 3). Fermentation of fibrous substrates by anaerobic bacteria in the large intestine leads to formation of SCFA, which promoted acidification of luminal contents (BORGES et al., 2003). This acidification can be reflected in faecal $\mathrm{pH}$. However, as in the present study no differences were observed with respect to the concentrations of SCFA in faeces, the fermentation processes were similar between animals that received the different diets. Thus, it can explain the absence of differences related to faecal $\mathrm{pH}$.

Fermentability is a characteristic more commonly associated with soluble fibre. However, it may be reported to a lesser extent in insoluble fibres (HOWARTH et al., 2001). While WB is considered a source of insoluble fibre, it presents arabinoxylans in its constitution, which have the property of retaining water and promoting the viscosity of solutions (SCHOONEVELD-BERGMANS et al., 1999). Thus, the fermentation observed in this study may be associated with arabinoxylans from WB. FISCHER et al. (2012) observed a higher faecal concentration of propionate in cats fed with a diet supplemented with wheat bran (140.53 mmol kg-1 DM) compared to animals fed with the control diet (without fibre supplementation)
$(72.93 \mathrm{mmol} / \mathrm{kg} \mathrm{DM})$, confirming that this ingredient undergoes a certain degree of fermentation. Furthermore, the fermentation observed can also be associated with CGF, since corn fibre presents in vitro fermentability (GUEVARA et al., 2008).

Blood concentrations of acetate and acetate + propionate did not differ $(\mathrm{P}>0.05)$ among diets and different sampling times, while blood concentrations of propionate were higher in cats fed with the feed 1 , which is composed by wheat bran as the only source of fibre, compared to cats fed with the other feeds at 4 and 8 hours after consumption (Table 3). At 8 hours after consumption, blood concentrations of propionate were similar between cats fed with feeds 1 and 3, but this could be due to individual variations related to the fermentation of substrates. According to FISCHER et al. (2012), faecal concentrations of propionate were higher in cats fed with diets supplemented with WB than in cats fed with diets supplemented with sugarcane fibre, which is primarily a source of insoluble fibre as well as the CGF. But, since no differences were observed in faecal SCFA concentrations in the present study, this difference in blood propionate concentrations could

Table 3 - Concentrations of short chain fatty acids (SCFA) in faeces and in blood at different collection times (hours) of cats fed diets with different amounts of corn gluten feed without steep water (CGF) substituted for wheat bran.

\begin{tabular}{|c|c|c|c|c|c|}
\hline & \multicolumn{4}{|c|}{---------------------------Inclusion of CGF $\left(\mathrm{g} \mathrm{kg}^{-1}\right)$------------------------- } & \multirow{2}{*}{ P-value } \\
\hline & 0 & 26 & 53 & 80 & \\
\hline \multicolumn{6}{|l|}{---------- } \\
\hline Total SCFA & $420.34 \pm 89.91$ & $494.30 \pm 80.90$ & $473.28 \pm 189.53$ & $522.31 \pm 165.53$ & 0.34 \\
\hline Acetate & $210.84 \pm 88.12$ & $243.10 \pm 54.44$ & $220.49 \pm 92.93$ & $230.78 \pm 80.93$ & 0.26 \\
\hline Propionate & $94.58 \pm 23.52$ & $98.81 \pm 29.57$ & $113.93 \pm 52.26$ & $102.30 \pm 31.11$ & 0.25 \\
\hline Isobutirate & $9.23 \pm 1.84$ & $6.99 \pm 2.92$ & $9.54 \pm 2.89$ & $8.40 \pm 2.27$ & 0.18 \\
\hline Butirate & $52.98 \pm 18.93$ & $76.15 \pm 38.78$ & $70.56 \pm 36.05$ & $84.34 \pm 35.99$ & 0.65 \\
\hline Isovalerate & $13.41 \pm 4.28$ & $11.44 \pm 3.99$ & $13.24 \pm 5.26$ & $13.65 \pm 3.29$ & 0.73 \\
\hline Valerate & $35.73 \pm 10.82$ & $41.33 \pm 14.53$ & $46.42 \pm 27.38$ & $54.35 \pm 20.81$ & 0.47 \\
\hline \multirow{2}{*}{\multicolumn{6}{|c|}{ Acetate }} \\
\hline & & & & & \\
\hline Pre-feeding & $3.38 \pm 1.28$ & $2.77 \pm 0.58$ & $2.73 \pm 0.98$ & $3.22 \pm 0.71$ & 0.76 \\
\hline 4 hours post-feeding & $2.46 \pm 0.49$ & $2.79 \pm 0.52$ & $2.76 \pm 0.33$ & $3.24 \pm 1.24$ & \\
\hline 8 hours post-feeding & $3.56 \pm 1.73$ & $2.93 \pm 0.68$ & $3.51 \pm 1.11$ & $3.20 \pm 0.99$ & \\
\hline \multicolumn{6}{|l|}{ Propionate } \\
\hline Pre-feeding & $2.63 \pm 1.21^{\mathrm{B}}$ & $2.23 \pm 1.06$ & $2.41 \pm 1.50$ & $2.42 \pm 1.67$ & 0.04 \\
\hline 4 hours post-feeding & $4.72 \pm 1.29^{\mathrm{Aa}}$ & $2.30 \pm 0.95^{\mathrm{b}}$ & $2.79 \pm 1.95^{b}$ & $2.78 \pm 2.11^{b}$ & \\
\hline 8 hours post-feeding & $4.53 \pm 2.12^{\mathrm{Aa}}$ & $2.27 \pm 1.02^{\mathrm{b}}$ & $3.60 \pm 1.46^{\mathrm{ab}}$ & $2.87 \pm 1.69^{\mathrm{b}}$ & \\
\hline \multicolumn{6}{|l|}{ Acetate + Propionate } \\
\hline Pre-feeding & $5.61 \pm 1.63$ & $4.99 \pm 0.77$ & $5.14 \pm 1.85$ & $5.43 \pm 1.83$ & 0.61 \\
\hline 4 hours post-feeding & $6.43 \pm 0.69$ & $5.09 \pm 1.28$ & $5.55 \pm 1.91$ & $6.01 \pm 2.82$ & \\
\hline 8 hours post-feeding & $6.75 \pm 1.97$ & $5.20 \pm 1.48$ & $6.70 \pm 1.74$ & $6.07 \pm 2.57$ & \\
\hline
\end{tabular}

${ }^{\mathrm{A}, \mathrm{b}}$ Means followed by different capital letters in columns and lower case letters in lines differ by the Kruskal Wallis test $(\mathrm{P}<0.05)$. 
be due to differences in the absorption processes between animals. Furthermore, blood concentrations of propionate were higher at 4 and 8 hours after consumption in cats fed with feed 1 , demonstrating that WB fermentation lasts for several hours in the GIT of these animals. This study is the first to measure blood concentrations of SCFA in cats. About 95 to $99 \%$ of these SCFA are readily absorbed by the intestinal mucosa (SCHEPPACH, 1994). Thus, based on the results observed, it can be confirmed that absorption of SCFA by the intestinal cells of cats also occurs to a significant degree, since significant amounts of acetate and propionate were detected in the blood of these animals. Butyrate is generally used by intestinal cells as a readily available energy source (BORGES et al., 2003). Thus, most of what is produced in the intestinal lumen is retained in the colonocytes and only a small fraction enters the blood, which may explain the nondetection of this SCFA in the blood.

In the present study, no differences were observed related to intestinal gas area between the experimental diets, which was to be expected, since the concentrations of SCFA in faeces did not differ between animals in the different groups.

\section{CONCLUSION}

Substitution of wheat bran with CGF up to a level of $8 \%$ can be done safely without impairing nutrient digestibility, faecal characteristics or fermentation in the GIT.

\section{ACKNOWLEDGEMENTS}

This study was made possible by a cooperation between the Universidade Federal de Lavras (UFLA) and the Universidade de São Paulo (USP). The authors thank the companies Ingredion Brasil - Ingredientes Industriais Ltda, Manfrim - Manfrim Industrial e Comercial Ltda, and Celta Brasil - Indústrias Celta Brasil Ltda, as well as the companion animal nutrition crew of the Universidade Federal de Lavras (UFLA) for their input to this study.

\section{BIOETHICS AND BIOSSECURITY COMMITTEE APPROVAL}

The experiment was approved by the Ethics Committee for Animal Use at the Universidade Federal de Lavras (UFLA) (protocol number 005/2015).

\section{REFERENCES}

ANFAL Pet (ASSOCIAÇÃO NACIONAL DOS FABRICANTES DE ALIMENTOS PARA ANIMAIS DE ESTIMAÇÃO). Manual do programa integrado de qualidade pet. São Paulo, SP, Brasil, 2009. $603 \mathrm{p}$.
AOAC (ASSOCIATION OF OFFICIAL ANALYTICAL CHEMISTS). Official methods of analysis. 16. ed. Washington, DC, USA, 1995. 1141 p.

BERGMANS, M. E. F. et al. Optimisation of the selective extraction of (glucorono) arabinoxylans from wheat bran: use of barium and and calcium hydroxide solution at elevated temperatures. Journal of Cereal Science, v.23, p.235-245, 1996. Available from: <http:// www.sciencedirect.com/science/article/pii/S0733521096900247>. Accessed: Mar. 15, 2016.

BORGES, F. M. et al. Recentes avanços na nutrição de cães e gatos. In: SIMPÓSIO SOBRE NUTRIÇÃO DE ANIMAIS DE ESTIMAÇÃO, 3., 2003, Campinas, SP. Anais... Campinas: Colégio Brasileiro de Nutrição Animal, 2003. V.3, p.21-60.

DAVIDSON, M. H.; MCDONALD, A. Fiber: forms and functions. Nutrition Research, v.18,p.617-624, 1998. Available from: <http:// www.sciencedirect.com/science/article/pii/S0271531798000487>. Accessed: Mar. 15, 2016. doi:10.1016/S0271-5317(98)00048-7.

De-OLIVEIRA, L. D. et al. Effects of six carbohydrate sources on diet digestibility and post-prandial glucose and insulin responses in cats. Journal of Animal Science, v.86, p.2237-2246, 2008. Available from: $<$ http://www.ncbi.nlm.nih.gov/pubmed/18469063>. Accessed: Mar. 22, 2016. doi: 10.2527/jas.2007-0354.

FAHEY, G. C. et al. Dietary fiber for dogs: II. Iso-total dietary fiber (TDF) additions of divergent fiber sources to dog diets and their effects on nutrient intake, digestibility, metabolizable energy and digesta mean retention time. Journal of Animal Science, v.68, p.4229-4235, 1990. Available from: <https://www.animalsciencepublications.org/ publications/jas/articles/68/12/4229>. Accessed: Mar. 15, 2016. doi: 1990.68124229x.

FELICIANO, M. A. R. et al. Ultrasonographic and radiographic evaluations of the effects of supplementation with two types of probiotics on the gut of puppies. Arquivo Brasileiro de Medicina Veterinária e Zootecnia, v.62, p.1109-1116, 2010. Available from: <http://www.scielo. $\mathrm{br} /$ scielo.php?script=sci arttext\&pid=S0102-09352010000500013 $>$. Accessed: Mar.15, 2016. doi: 10.1590/S0102-09352010000500013.

FISCHER, M. M. et al. Fiber fermentability effects on energy and macronutrient digestibility, fecal traits, postprandial metabolite responses, and colon histology of overweight cats. Journal of Animal Science, v.90, p.2233-2245, 2012. Available from: $<$ https://www.animal sciencepublications.org/publications/jas/articles/90/7/2233>. Accessed: Mar. 15, 2016.

FORTES, C. M. L. S. et al. Digestibility and metabolizable energy of some carbohydrates sources for dogs. Animal Feed Science and Technology, v.156, p.121-125, 2010. Available from: <http:// www.sciencedirect.com/science/article/pii/S0377840110000258>. Accessed: Mar. 15, 2016. doi: 10.1016/j.anifeedsci.2010.01.009.

GUEVARA, M. A. et al. Chemical composition, in vitro fermentation characteristics, and in vivo digestibility responses by dogs to select corn fibers. Journal of Agricultural and Food Chemistry, v.56, p.1619-1626, 2008. Available from: $<$ http://pubs. acs.org/doi/abs/10.1021/jf073073b>. Accessed: Mar. 15, 2016.

HOWARTH, N. C. et al. Dietary fiber and weight regulation. Nutrition Reviews, v.59, p. 129-139, 2001. Available from: $<$ http://nutritionreviews.oxfordjournals.org/content/59/5/129. long>. Accessed: Mar. 15, 2016. 
KAWAUCHI, I. M. et al. Digestibility and metabolizable energy of maize gluten feed for dogs as measured by two different techniques. Animal Feed Science and Technology, v.169, p. 96-103, 2011. Available from: $<$ http:// www.sciencedirect.com/science/article/pii/S0377840111002677>. Accessed: Mar. 15, 2016.doi:10.1016/j.anifeedsci.2011.05.005.

KIENZLE, E. et al. Investigation on palatability, digestibility and tolerance of low digestible food components in cats. Journal of Nutrition, v.121, p.56-57, 1991. Available from: <http://jn.nutrition. org/content/121/11_Suppl/S56.full.pdf>. Accessed: Mar. 15, 2016.

MAES, C. et al. Relative activity of two endoxylanases towards water-unextractablearabinoxylans in wheat bran. Journal of Cereal Science, v.39, p.181-186, 2004. Available from: <http:// www.sciencedirect.com/science/article/pii/S0733521003000730> Accessed: Mar. 15, 2016. doi: 10.1016/j.jcs.2003.08.001.

NRC (NATIONAL RESEARCH COUNCIL). Nutrient requirements of dogs and cats. Washington, DC: National Academy, 2006. 398 p.

ROBERTSON, J. B.; VAN SOEST, P. J. The detergent system of analyses. In: JAMES, W. P. T.; THEANDER, O. The analyses of dietary fibre in food. New York: Marcel Dekker, 1981. Chap.6, p.123-158.

SCHEPPACH, W. Effects of short chain fatty acids on gut morphology and function. Gut, suppl.1, p.S35-S38, 1994. Available from: <http://gut.bmj.com/content/35/1_Suppl/S35.full.pdf + html $>$. Accessed: Mar. 15, 2016.

SCHOONEVELD-BERGMANS, M. E. F. et al. Structural features of (glucorono) arabinoxylans extracted from wheat bran by barium hydroxide. Journal of Cereal Science, v.29, p.63-75, 1999. Available from: $<$ http://www.sciencedirect.com/science/article/pii/ S073 $3521098902223>$. Accessed: Mar. 15, 2016.

SUGAWARA, M. et al. Composition of corn hull dietary fiber. Starch, v.46, p.335-337, 1994. Available from: <http:/ onlinelibrary.wiley.com/doi/10.1002/star.19940460904/pdf>. Accessed: Mar. 15, 2016. doi: 10.1002/star.19940460904.

SUNVOLD, G. D. et al. Dietary fiber for cats: In vitro fermentation of selected fiber sources by cat fecal inoculum and in vivo utilization of diets containing selected fiber sources and their blends. Journal of Animal Science, v.73, p.2329-2339, 1995. Available from: $<$ https://www.animalsciencepublications.org/publications/jas/ articles/73/8/2329>. Accessed: Mar. 15, 2016.doi: 1995.7382329x.

VAN SOEST, P. J. Use of detergents in the analysis of fibrous feed II. A rapid method of the determination of fiber and lignin. Journal of the Association of Official Agricultural Chemists, v.46, p.829-835, 1963. Available from: <http://catalogo.latu.org. uy/doc_num.php ?explnum_id=1479>. Accessed: Mar. 15, 2016. 